\title{
Assessment of Iron Status in a Sample of Infants Aged 6-12 Months in Jerash Governorate, Jordan
}

\author{
Sara L. Hussein and Hamed R. Takruri \\ Department of Nutrition and Food Technology/ Human Nutrition and Dietetics, Faculty of Agriculture, The \\ University of Jordan, Amman 11942, JORDAN
}

\begin{abstract}
Abstarct
This study aimed at investigating the relationship between iron status and the type of milk and weaning solid foods in a group of infants aged 6 - 12 months in Sakeb Health Center in Jerash Governorate, Jordan. In this crosssectional study, a sample of 119 infants (59 females, 60 males), were recruited, A special questionnaire was used to collect socioeconomic data for the infants' families, and three- day food recall was also used to collect infants dietary intake data. Body weight, length and head circumference were measured, and z-score was calculated for evaluating the anthropometric status. Hemoglobin ( $\mathrm{Hb})$, mean cell volume (MCV) and serum ferritin concentrations (SF) were measured on nonfasting venipuncture blood samples. The studied sample was divided into three groups according to type of feeding: exclusively breastfed group $(n=41)$, formula-fed group ( $n=49)$ and mixed-fed group ( $\mathrm{n}=29$ ). The results showed that among infants with $\mathrm{Hb}<110 \mathrm{~g} / \mathrm{l}, \mathrm{MCV}<70 \mathrm{fl}$ and $\mathrm{SF}<12 \mu \mathrm{g} / \mathrm{l}$, $10.1 \%$ had iron deficiency anemia (IDA). Anemia was found in 36.9\% when hemoglobin cutoff was taken to be $<110 \mathrm{~g} / \mathrm{l}$, and depleted iron stores were found in $27.7 \%$ using a ferritin cutoff $<12 \mu \mathrm{g} / 1$. Among the breastfed group, incidence of IDA, anemia and depleted iron stores were the highest compared to the other two groups. No significant differences for $\mathrm{Hb}, \mathrm{MCV}$, and SF values existed between males and females although female infants tended to have higher hemoglobin, MCV, and serum ferritin values than male infants.Mean intake of iron was the highest among infants of formula-fed group ( $7.82 \mathrm{mg} /$ day), as compared with breastfed and mixed-fed groups ( 2.75 and $4.23 \mathrm{mg}$ /day respectively). No significant differences were observed between infants in any of the anthropometric measurements. Based on z-score, $1.7 \%$ of infants in breastfed group and formula-fed group were stunted compared with $0.8 \%$ in the mixed-fed group, whereas $2.5 \%$ of infants were overweight in the formula-fed group.It could be concluded that iron deficiency is common in infants in Jerash Governorate, since up to $10 \%$ of the recruited infants developed IDA, 37\% developed anemia, and 28\% had depleted iron stores.
\end{abstract}

Keywords: iron, iron deficiency, anemia, breastfeeding, formula feeding

DOI: $10.7176 / \mathrm{JHMN} / 59-05$

\section{Introduction}

Infancy is a critical period of growth and brain development, and over this period micronutrient deficiencies, specifically iron deficiency (ID), could lead to cognitive impairment and cause a serious hazard to long term development (Atkins et al., 2016; Qasem, 2015, Black et al., 2008,). Iron is particularly important in fetal-maternal nutrition (Mosha et al., 2016). Anemia in early pregnancy, particularly "iron deficiency anemia" (IDA), is associated with increased risk of adverse outcomes of pregnancy, higher rates of preterm delivery, lower birth weight and poor neonatal iron stores (Scholl, 2011).

IDA most commonly affects infants 6 - 12 months old due to incremented needs for iron, which their diet cannot provide (Pasricha et al., 2013). Also many dietary factors affect iron bioavailability and lead to increased loss of iron such as phytates (bread) and tannins (tea) (WHO, 2001). Additionally, it was found that infants and children who consume whole cow milk are at higher risk to develop iron deficiency anemia. Not only cow milk is a poor source of iron, but also it increases the amount of occult intestinal blood loss (Ziegler, 2011; Sabri, 2001).

Hopkins et al. (2007) concluded that there is an association between hemoglobin concentrations and iron stores at 8 and 12 months and the type of milk fed at 8 months. At that age range, both cow milk and human milk feeding were correlated with lower indices of ferritin and a higher incidence of anemia than formula feeding. Assessing iron status in infancy is important since infants over 6 months of age and toddlers are at high risk to develop ID because they require more iron for growth. This high need increases with age when body iron stores are depleted, dietary patterns are not yet well developed and intakes of meat are often low (Soh et al., 2004).

Iron deficiency anemia is the most common nutrient deficiency in the developed world, especially among infants and young children (Hopkins et al., 2007). Many studies that assessed the iron status in infants and young children found a relationship between iron deficiency anemia and impaired cognitive and psychomotor development. These studies have attracted a massive consideration since iron deficiency anemia is common among this age group (Krebs et al., 2017). Treatment with iron can reestablish iron sufficiency and reverse the anemia, but the poorer developmental functions still persist, thereby, intervention should focus on the primary prevention of iron deficiency (Beard, 2008). Therefore, the objective of this study is to assess the nutritional status of iron in infants according to type of milk and certain foods consumed and to identify the factors related to iron status and the type of feeding in healthy term infants aged 6-12 months in Jerash Governorate. 


\section{Subjects and Methods}

\subsection{Subjects}

A convenient sample consisted of 119 healthy full term infants, aged 6-12 months (60 males and 59 females). They were recruited randomly from Sakeb Health Care Center in Jerash Governorate, between October 2014 and November 2015. Inclusion criteria were: being full term infants, apparently healthy, and those who were not subjected to serious medical treatment. The criteria were obtained from the infant's file by the nurse and the researcher. The exclusion criteria of the infants included the presence of chronic diseases, presence of diarrhea, those who ever received iron supplements, preterm infants and children born to iron-deficient mothers. Also infants from iron deficient mothers at the time of the study were excluded to minimize confounding factors. One infant with thalassemia was diagnosed and excluded from the study.

The population sample consisted of 41 exclusively breastfed infants, 49 formula-fed infants and 29 mixedfed infants. The formula-milk group consisted of those who were fed formula with or without cow milk, whereas the mixed-fed group consisted of those who were fed breast milk with or without infant-formula and/or cow milk. Ethical approval was obtained from Sakeb Health Care Center and from the Deanship of Academic Research at the University of Jordan and the Ministry of Health. All participants' mothers received full information about the nature, objectives, and main method of the study prior to asking them to provide a written consent.

\subsection{Socioeconomic information}

Basic information was obtained about the infant including name, sex, date of birth and birth weight. Also the questionnaire included the information about the mother: age, educational level, family income, number of children, and relative's marriage.

\subsection{Health and life style information}

These included questions on the use of supplements by mothers and infants, and whether mothers were anemic during pregnancy.

\subsection{Dietary assessment}

Information on the current infant feeding practices was collected during the interview with the mother. For breastfed infants, information was collected about the frequency and duration of each feeding; for formula-fed infants information was collected about number of feeds per day, volume of each feed, type of formula, and the method of preparation. Infants' mothers were also requested to fill a three days food recall for their infants during the previous three days ( 2 week days and one weekend day). Mothers were thoroughly instructed on how to write the infants food intake and accurately describe food portion sizes, dish composition, food varieties, and preparation methods. Detailed information of all foods and beverages including brand names, method of preparation, and amount and ingredients of dishes were also collected.

\subsection{Anthropometric measurements}

Weight, length and head circumference of infants enrolled in the study were taken by the nurse at the time of the study following a standard procedure (Lee and Neiman, 2010). Infants were weighed to the nearest $0.05 \mathrm{~kg}$ using pan-type baby weighing electronic scale (Charder, China). Length was measured to the nearest $0.1 \mathrm{~cm}$ using a stadiometer (Seca, Germany). Head circumference was measured with a flexible, nonstretchable measuring tape to the nearest $0.1 \mathrm{~cm}$. Body mass index (BMI) was calculated as weight $(\mathrm{kg}) / \mathrm{length}\left(\mathrm{m}^{2}\right)$.

\subsection{Biochemical analysis}

A venous blood sample of about $4 \mathrm{ml}$ was obtained from the hand of the infant by a specialist nurse from the Neonatal Intensive-care Unit (NICU) at Jerash Hospital with a $5 \mathrm{ml}$ syringe. Blood sample of $2 \mathrm{ml}$ was collected in sterile vacuum tubes containing K3EDTA. These samples were analyzed on the same day by electronic count (sysmex k21), to determine complete blood count. Another blood sample of $2 \mathrm{ml}$ was collected in another sterile vacuum tube containing gel that accelerated clotting in order to obtain serum for ferritin analysis. The samples for serum ferritin analysis were centrifuged on the same day of collection and ferritin measurement was done at modular cobas 6090 seq: 32290 and results were obtained. The following cut-offs recommended by WHO were used: Hemoglobin $(\mathrm{Hb})<110 \mathrm{~g} / \mathrm{l}, \mathrm{MCV}<70 \mathrm{fl}, \mathrm{SF}<12 \mu \mathrm{g} / \mathrm{l}$ (WHO, 2001; WHO, 2017). Anemia was defined as $\mathrm{Hb}<110 \mathrm{~g} / \mathrm{l}$, and depleted iron stores as $\mathrm{SF}<12 \mu \mathrm{g} / \mathrm{l}$. Iron deficiency anemia (IDA) was defined as $\mathrm{Hb}<110 \mathrm{~g} / \mathrm{l}+$ $\mathrm{MCV}<70 \mathrm{fl}+\mathrm{SF}<12 \mu \mathrm{g} / 1$.

\subsection{Statistical analysis}

Statistical analysis was performed using the statistical package for social sciences, version 22 (SPSS for Windows, Rel. 22.0. 2013 Chicago: SPSS Inc.). Descriptive statistics was used to describe the demographic data of the sample population. Two independent t-tests and one -way analysis of variance (ANOVA) were used to determine whether 
there are any significant differences between the means of categorical variables. Two-way ANOVA was used to obtain significant differences between the mean of variables according to the interaction between two factors. Post hoc tests (Tukey and Bonferroni tests) were developed to compare the means and percentage of the variables and exploration of the differences among them. Chi square test was constructed to measure if there is any significant difference between categorical variables.

\section{Results}

A total of 119 infants enrolled in this study were divided according to their type of feeding into: exclusively breastfed, formula-fed and mixed-fed infants. Socio demographic characteristics of the sample population are presented in Table 1. There were no significant differences in descriptors of socio-demographic status between the breast-fed infant group, formula-fed infant group and mixed-fed infant group with respect to infant sex, birth weight, family number, family income, mother's age, mother's educational level, mother's assistance in child feeding and relatives' marriage.

Table 2 shows the dietary characteristics of the study groups according to infant's age. Findings indicate that there were no significant differences in energy intake (kcal/day), CHO intake (g/day) and fat intake (g/day) among infants of different age groups. In addition, there were no significant differences in protein intake (g/day) among infants at different ages. On the other hand, among infants at 6 and 7 months of age, vitamin $\mathrm{C}$ intake (mg/day) was significantly $(\mathrm{P}<0.05)$ higher compared to that of infants between 8-9 and 10-12 months of age. There were no significant differences in calcium intake (mg/day) between infants at different ages. Among infants $6-7$ months of age, iron intake was significantly $(\mathrm{P}<0.05)$ higher compared to infants between 8-9 and 10-12 months of age.

Table 3 demonstrates the percentage of infant whose energy intake was lower than $80 \%$ or higher than $120 \%$ of DRI. At 6 months of age, 3 infants $(2.5 \%)$ had lower than $80 \%$ of the recommended intake of energy, whereas 1 infant $(0.8 \%)$ at 7 months of age had lower than $80 \%$ of the recommended intake of energy, compared to 2 infants $(1.7 \%)$, who had above $120 \%$ of the recommended intake at the same age. Also 1 infant $(0.8 \%)$, at 8 months of age had lower than $80 \%$ of the recommended intake of energy, while 12 infants $(10.1 \%)$ at 9 months of age had lower than $80 \%$ of the recommended intake of energy. At the same age, 2 infants $(1.7 \%)$ were above $120 \%$ of the recommended intake of energy, $15(12.6 \%)$ at 10 months of age had lower than $80 \%$ of the recommended intake of energy, 23 infants $(19.3 \%)$ at 11 months of age had lower than $80 \%$ of the recommended intake of energy, compared to 3 infants $(2.5 \%)$ who had above $120 \%$ of the recommended intake of energy, and $11(9.2 \%)$ infants at 12 months of age had lower than $80 \%$ of the recommended intake of energy.

The mean iron intake and its percent from recommendation (DRI) by infants according to type of feeding and age are given in table (4). It was found that the mean values of total intake of iron in breastfed, formula-fed and mixed-fed infants were $2.75 \pm 2.66,7.82 \pm 5.94$ and $4.23 \pm 2.36 \mathrm{mg} /$ day respectively. It is apparent that the mean value of total iron intake was the highest $(7.82 \pm 5.94)$ in the formula-fed group but without any significant difference among the breastfed, formula-fed and mixed-fed groups or between age groups. As a percent of recommended iron intake, the breastfed, formula-fed and mixed-fed infants got 24.84 $\pm 24.23,65.11 \pm 41.12$ and $38.38 \pm 21.53 \%$ respectively. The mean percent of recommended iron intake was the highest $(65.11 \pm 41.12)$ in the formula-fed group but without any significant difference among the 3 groups.

Table 5 shows the anthropometric characteristics of infants according to sex. There was no significant difference between infants according to sex at all age groups.

Table 6 demonstrates the values of hemoglobin, MCV and serum ferritin of the infants according to type of feeding. As shown in the table, there was a significant $(\mathrm{P}<0.05)$ difference in hemoglobin level among breastfed, formula-fed and mixed fed infants.

Table 7 shows the incidence of iron deficiency anemia (IDA), anemia and depleted iron stores according to type of feeding. Nine infants (7.6\%) had IDA, $(\mathrm{Hb}<110 \mathrm{~g} / \mathrm{l}, \mathrm{MCV}<70 \mathrm{fl}$ and serum ferritin of $<12 \mu \mathrm{g} / \mathrm{l})$, whereas 22 infants $(18.5 \%)$ had anemia $(\mathrm{Hb}<110 \mathrm{~g} / \mathrm{l})$, and 22 infants $(18.5 \%)$ had depleted iron stores (serum ferritin $<12$ $\mu \mathrm{g} / \mathrm{l})$ in the breastfed group. However, among the formula-fed group, the incidence of IDA, anemia, and depleted iron stores were $3(2.5 \%), 13(10.9 \%)$ and $7(5.8 \%)$ respectively. Whereas, among the mixed-fed group, the incidence of IDA, anemia, and depleted iron stores were $4(0 \%), 9(7.6 \%)$ and $4(3.4 \%)$, respectively.

Table 8 shows the mean values of $\mathrm{Hb}, \mathrm{MCV}$, and serum ferritin for all study groups. There were 44 infants (36.9\%) who had anemia $(\mathrm{Hb}<110 \mathrm{~g} / \mathrm{l}), 12$ infants $(10.1 \%)$ who had iron deficiency anemia $(\mathrm{Hb}<110 \mathrm{~g} / \mathrm{l}, \mathrm{MCV}$ $<70 \mathrm{fl}$ and serum ferritin $<12 \mu \mathrm{g} / \mathrm{l})$ and about $33(27.7 \%)$ infants had depleted iron stores (serum ferritin $<12 \mu \mathrm{g} / \mathrm{l}$ ).

\section{Discussion}

Iron deficiency is considered one of the most common micronutrient deficiencies in the world. Preschool children, in particular, are reported to be victims of iron deficiency anemia. The aim of this study was to investigate the nutritional status of iron in a sample of healthy infants in Jerash Governorate aged 6-12 months through assessing the dietary intake of iron in infants according to type of feeding. The importance of this study comes from the fact that there is scarcity of data on nutritional assessment of iron among infants in Jordan, as related to type of feeding. 
Few studies have shown that a high prevalence of ID and IDA are common among infants and young children in the developing countries and Jordan (Nusair et al., 2011; Lutter, 2008; Dewey and Chaparro, 2007; Lozoff. 2007; Siti-Noor et al., 2006). This could be attributed to prolonged breastfeeding beyond six months of age (Dewey and Chaparro, 2007). Our results seem to be consistent with those studies; breastfed infants had the lowest mean of hemoglobin $(105.43 \pm 12.04 \mathrm{~g} / \mathrm{l})$, compared with formula-fed infants and mixed-fed infants $(115.12 \pm 9.19 \mathrm{~g} / \mathrm{l})$ and $(112.89 \pm 9.15 \mathrm{~g} / \mathrm{l})$ respectively. Also breastfed infants had lower mean MCV (69.95 $\pm 7.21 \mathrm{fl})$, compared with formula-fed infants and mixed-fed infants $(71.39 \pm 4.40 \mathrm{fl})$ and $(71.31 \pm 5.21 \mathrm{fl})$ respectively. In addition, breastfed infants had lower mean serum ferritin $(28.51 \pm 71.43 \mu \mathrm{g} / \mathrm{l})$, compared with formula-fed infants and mixed-fed infants $(39.16 \pm 41.23 \mu \mathrm{g} / \mathrm{l})$ and $(39.68 \pm 30.03 \mu \mathrm{g} / \mathrm{l})$ respectively.

The results of the current study show that there were no significant differences in mean energy intake among different age groups. However, more than half of infants in the whole sample $(55.5 \%)$ had energy intake $<80 \%$ of DRI, and only 5.7\% had energy intake >DRI. The mean energy intake was $721.8 \mathrm{kcal} / \mathrm{day}$. In contrast to our results Atkins et al. (2016) showed that mean energy intake was $841 \mathrm{kcal} / \mathrm{day}$.

Mean carbohydrates intake was $94.7 \mathrm{~g} /$ day for the whole sample. The findings of our study may indicate adequate intake of carbohydrate for infants.

Mean fat intake was $32 \mathrm{~g} /$ day for the whole sample: There was no significant difference in fat intake among different age groups. This supported the results of Qasem (2015) who found that fat intake did not rise significantly after displacement of breast milk intake by complementary foods (Qasem, 2015).

Mean protein intake was $21.7 \mathrm{~g} /$ day for the whole sample. There was no significant difference in protein intake among the different age groups, although mean protein intake increased with age. This could be due to high consumption of cow milk with age by Jordanian infants; cow milk is not only high in protein and could increase risk of adiposity in later childhood, but also it inhibits the non-heme iron absorption (Ziegler, 2011).

Regarding micronutrient intake, mean vitamin $\mathrm{C}$ intake was $60.6 \mathrm{mg} /$ day for the whole sample with no significant differences among different age groups.Vitamin $\mathrm{C}$ (ascorbic acid) is regarded as key dietary enhancer of iron absorption and foods containing vitamin $\mathrm{C}$ can increase absorption by $200 \%$ to $300 \%$ when eaten with nonheme foods (Collings et al., 2013; Jarrah et al., 2007).

Regarding the mean calcium intake, it was $632.8 \mathrm{mg} /$ day for the whole sample with no significant differences among different age groups. This result is very high compared with adequate intake of calcium, and it could affect the iron status of infants, and seems to be consistent with the results of Hopkins et al. (2007). These authors found a negative association between calcium intake and ferritin concentrations. They suggested that for every standard deviation increase (about $250 \mathrm{mg}$ ) in calcium content of the diet there would be drop in mean ferritin concentration by about $20 \%$. In addition, Hallberg and Hulthen (2000) reported that calcium inhibited the absorption of heme and non heme iron as well.

Mean iron intake by the whole sample was $(5.20 \pm 4.70 \mathrm{mg} /$ day $)$ which is equivalent to $44.4 \%$ of the recommendation and thus it is inadequate. Our results showed that $83.2 \%$ of infants had iron intake below $80 \%$ of dietary reference intake. This is consistent with the results of Atkins et al. (2016). We found that the mean total iron intake was the highest $(7.82 \pm 5.94 \mathrm{mg} /$ day $)$ in the formula-fed group but without any significant difference $(\mathrm{P}>0.05)$ in intake among the breastfed, formula-fed and mixed-fed groups or between age groups. It is apparent in this study that, the main food sources of iron for infants were iron fortified infant formula and iron fortified weaning foods. This is similar to the results of Atkins et al. (2016) who found that the main food sources of iron for infants were the infant formula, iron fortified infant products, and cereals. It is also similar to the results of Faqih and Qazaq (1999) who reported that the iron-fortified weaning foods are typical weaning foods consumed by the Jordanian infants.

\section{Anthropometric measurements}

The results of the current study show a significant difference $(\mathrm{P}<0.05)$ in growth between infants with respect to age. As expected, infants aged 10,11 and 12 months had a higher weight, length and head circumference, $(9.59 \pm$ $1.05 \mathrm{~kg}),(72.58 \pm 8.41 \mathrm{~cm})$ and $(44.43 \pm 1.69 \mathrm{~cm})$ respectively. There was no significant difference in growth between sex groups, which is consistent with the results of Thorsdottir et al., (2003) who did not find a difference in growth between the sex groups in the study population.

\section{Hemoglobin, MCV and serum ferritin values of the study groups}

The present study found significant differences $(\mathrm{P}<0.05)$ in hemoglobin concentrations among breastfed, formulafed and mixed-fed infants. Lower hemoglobin concentration in breastfed infants compared with formula-fed infants could be due to iron fortification with infant formula and the low value of iron obtained by breastfeeding (Domellof et al., 2014). This is consistent with the results of Chandyo et al. (2015) who found lower hemoglobin and ferritin concentrations in infants who were exclusively breastfeed for more than 3 months, which is a reflection of the low iron content of breast milk.

There was no significant difference $(\mathrm{P}<0.05)$ between MCV and serum ferritin with the type of milk feeding, 
although serum ferritin was low among breastfed infants and this could be due to the low iron content of breast milk as mentioned above (Chandyo et al., 2015).

Our results show that more than one third (36.9\%) of infants developed anemia, $(10.1 \%)$ had iron deficiency anemia and about (27.7\%) infants had depleted iron stores. The prevalence of anemia, IDA, and depleted iron stores were consistent with Domellof et al. (2014) who found a high prevalence of IDA and depleted iron stores during infancy period.

Regarding type of milk feeding, our results show that the prevalence of IDA, anemia, and depleted iron stores among breastfed group was the highest compared with formula-fed and mixed-fed groups. This was consistent with the results of Hopkins et al. (2007), who found that both breast milk and cow milk feeding were associated with lower indices of ferritin and a higher incidence of anemia than formula feeding.

\section{Conclusions}

- Iron deficiency is common in infants in Jerash Governorate.

- Up to $10 \%$ of Jordanian infants in Sakeb/Jerash 6-12 months-old developed IDA, 37\% developed anemia and $28 \%$ had depleted iron stores.

- Iron intakes may be inadequate in the Jordanian infants despite the consumption of iron fortified foods.

- Most healthy term infants do not need exogenous iron during the first 4-6 months of age, but they do after that time when their need increases dramatically.

\section{Study Limitations}

- The relatively small sample size.

- The subjects are not equally distributed in the sample groups according to infant's age which may affect the comparisons.

- The dietary intake was obtained from infant's mothers and depended on self-recall which may lead to some bias because it relies on their memory.

- Although the quantity of recorded food items was determined according to given instructions and food samples, and is expected to be close to the actual amount; however it could be over or under-estimated.

\section{Acknowledgment}

The authors would like to thank the deanship of academic research at The University of Jordan, Amman Jordan for the financial support.

\section{References}

Atkins LA, McNaughton SA, Campbell KJ and Szymlek-Gay EA. (2016). Iron intakes of Australian infants and toddlers: findings from the Melbourne infant feeding, activity and nutrition trial (InFANT) program. $\mathrm{Br} J$ Nutr, 115: 285-293.

Beard JL. (2008). Why iron deficiency is important in infant development. J Nutr, 138: 2534-2536.

Black RE, Allen LH, Bhutta ZA, Caulfield LE, de Onis M, Ezzati M, Mathers C and Rivera J. (2008). Maternal and child undernutrition: global and regional exposures and health consequences. Lancet, 371: 243-260.

Chandyo RK, Henjum S, Ulak M, Thorne- Lyman AL, Ulvik RJ, Shrestha PS, Locks L, Fawzi W and Strand TA. (2015). The prevalence of anemia and iron deficiency is more common in breastfed infants than their mothers in Bhaktapur, Nepal. Eur J Clin Nutr, 70: 456-62.

Collings R, Harvey LJ, Hooper L, Hurst R., Brown TJ, Ansett J, King M and Fairweather-Tait, SJ. (2013). The absorption of iron from whole diets: a systematic review. Am J Clin Nutr, 98: 65-81

Dewey KG and Chaparro CM. (2007). Session 4: mineral metabolism and body composition iron status of breastfed infants. Proc Nutr Soc, 66: 412-422.

Domellof M, Braegger C, Campoy C, Colomb V, Decsi T, Fewtrell M, Hojsak I, Mihatsch W, Molgaard C, Shamir R, Turck D and Goudoever JV. (2014). Iron requirements of infants and toddlers. Eur Soc Paediatr Gastroenterol Hepato Nutr, 58: 119-129.

Faqih AM and Qazaq HS. (1999). Development of iron-deficiency anaemia at six months of age in Jordanian infants exclusively breastfed for four to six months. Food Nutr Bull, 20: 422-528.

Hallberg L and Hulthén L. (2000). Prediction of dietary iron absorption: an algorithm for calculating absorption and bioavailability of dietary iron, Am J Clin Nutr, 71: 1147-1160.

Hopkins D, Emmett P, Steer C, Rogers I, Noble S and Emond A. (2007). Infant feeding in the second 6 months of life related to iron status: an observational study. Arc Dis Child, 92: 850-854.

Jarrah SS, Halabi JO, Bond AE and Abegglen J. (2007). Iron deficiency anemia (IDA) perceptions and dietary iron intake among young women and pregnant women in Jordan. J Transcult Nurs, 18: 19-27.

Krebs NF, Lozoff B and Georgieff MK. (2017). Neurodevelopment: The impact of nutrition and inflammation 
during infancy in low-resource settings. Pediatrics, 139: 2016-2828.

Lee R and Nieman D. (2010). Nutritional Assessment, fifth ed. New York: MC Graw Hill.

Lozoff B. (2007). Iron deficiency and child development. Food Nutr Bull, 28: S560-S571.

Lutter CK. (2008). Iron deficiency in young children in low-income countries and new approaches for its prevention. J Nutr, 138: 2523-2528.

Mosha D, Liu E, Hertzmark E, Chan G, Sudfeld C, Masanja H and Fawzi W.( 2016). Dietary iron and calcium intakes during pregnancy are associated with lower risk of prematurity, stillbirth and neonatal mortality among women in Tanzania. Public Health Nutr, 20:678-686.

Nusair Z, Al-Wraikat A, Abu Al-Shiekh N, Kofahi S and Zoubi M. (2011). The frequency of iron deficiency anemia and thalassemia trait among children: experience at Prince Rashed Bin al- Hassan military hospital. $J$ $R$ Med Serv, 18: 39-44.

Pasricha S, Drakesmith H, Black J, Hipgrave D and Biggs B. (2013). Control of iron deficiency anemia in lowand middle-income countries. Blood J, 121: 2607-2617.

Qasem WA. (2015). Assessment of Complementary Feeding of Canadian Infants, Doctoral Dissertation, University of Manitoba, Winnipeg.

Sabri S. (2001). Weaning pattern for a group of infants in Amman. Unpublished Masters Dissertation, University of Jordan, Amman.

Scholl TO. (2011). Maternal iron status: relation to fetal growth, length of gestation, and iron endowment of the neonate. Nutr Rev, 69: 23-29.

Siti-Noor A S, Wan-Maziah W M, Narazah M Y and Quah B S. (2006). Prevalence and risk factors for iron deficiency in Kelantanese pre-school children. Singapore Med J, 47: 935-9.

Soh P, Ferguson E L, McKenzie J E, Homs M YV and Gibson R S. (2004). Iron deficiency and risk factors for lower iron stores in 6-24-month-old New Zealanders. Eur J Clin Nutr, 58: 71-79.

Thorsdottir, Gunnarsson BS, Atladottir H, Michaelsen KF and Palsson G. (2003). Iron status at 12 months of age - effects of body size, growth and diet in a population with high birth weight. Eur J Clin Nutr, 57: 505513.

WHO (World Health Organization). (2001). Iron Deficiency Anaemia: Assessment, Prevention, and Control. A Guide for Programme Managers. Geneva, Switzerland. Retrieved from: http://www.who.int/nutrition/publications/en/ida_assessment_prevention_control.pdf

WHO (World Health Organization). (2017). Nutritional anaemias: tools for effective prevention and control. A Guide for Programme Managers. Geneva, Switzerland. Retrieved from: http://www.who.int/nutrition/publications/micronutrients/anaemias-tools-prevention-control/en/

Ziegler EE. (2011). Consumption of cow's milk as a cause of iron deficiency in infants and toddlers. Nutr Rev, 69: S37-S42. 
Table 1: Socio-demographic characteristics of the sample population

\begin{tabular}{|c|c|c|c|c|}
\hline Characteristic & $\begin{array}{c}\text { Breastfed } \\
\text { infants } \\
n=41\end{array}$ & $\begin{array}{c}\text { Formula-fed } \\
\text { infants } \\
n=49\end{array}$ & $\begin{array}{c}\text { Mixed-fed } \\
\text { infants } \\
\mathbf{n}=\mathbf{2 9}\end{array}$ & $\begin{array}{c}P- \\
\text { value }\end{array}$ \\
\hline \multicolumn{5}{|c|}{ Infant characteristics } \\
\hline $\begin{array}{r}\text { Infant sex N (\%) }(\% \text { male }) \\
(\% \text { female })\end{array}$ & $\begin{array}{l}20(48.8 \%) \\
21(51.2 \%)\end{array}$ & $\begin{array}{l}26(51.0 \%) \\
23(47.9 \%)\end{array}$ & $\begin{array}{l}14(48.3 \%) \\
15(51.7 \%)\end{array}$ & 0.93 \\
\hline Mean birth weight $(\mathrm{kg}) \pm \mathrm{SD}$ & $2.98 \pm 0.43$ & $3.06 \pm 0.52$ & $3.12 \pm 0.48$ & 0.48 \\
\hline \multicolumn{5}{|c|}{ Family characteristics } \\
\hline Mean family number \pm SD & $4.56 \pm 1.36$ & $4.66 \pm 1.89$ & $4.75 \pm 1.92$ & 0.89 \\
\hline Mean family income $(\mathrm{JD}) \pm \mathrm{SD}$ & $309.7 \pm 80.0$ & $358.4 \pm 137.8$ & $331.0 \pm 93.0$ & 0.11 \\
\hline Mother's mean age(years) \pm SD & $28.87 \pm 5.21$ & $29.22 \pm 5.69$ & $29.68 \pm 5.47$ & 0.83 \\
\hline \multicolumn{5}{|c|}{ Mother characteristics } \\
\hline $\begin{array}{l}\text { Mother's educational level } \\
\text { Basic } \\
\text { Secondary } \\
\text { Diploma } \\
\text { University } \\
\text { Postgraduate }\end{array}$ & $\begin{array}{c}3(7.3 \%) \\
24(58.5 \%) \\
3(7.3 \%) \\
11(26.8 \%) \\
0(0 \%)\end{array}$ & $\begin{aligned} 2 & (4.2 \%) \\
17 & (35.4 \%) \\
4 & (8.3 \%) \\
22 & (45.8 \%) \\
3 & (6.3 \%)\end{aligned}$ & $\begin{array}{c}1(3.4 \%) \\
11(37.9 \%) \\
3(10.3 \%) \\
13(44.8 \%) \\
1(3.4 \%)\end{array}$ & 0.43 \\
\hline $\begin{array}{l}\text { Mother's assistance in child Feeding } \\
\text { Yes (\%) } \\
\text { Relatives } \\
\text { Nursery } \\
\text { Assistant } \\
\text { Maid }\end{array}$ & $\begin{array}{c}35(85.4 \%) \\
1(2.4 \%) \\
4(9.8 \%) \\
1(2.4 \%)\end{array}$ & $\begin{array}{c}40(83.3 \%) \\
4(8.3 \%) \\
2(4.2 \%) \\
2(4.2 \%)\end{array}$ & $\begin{array}{c}27(93.1 \%) \\
1(3.4 \%) \\
0(0 \%) \\
1(3.4 \%)\end{array}$ & 0.51 \\
\hline $\begin{array}{r}\text { Relative's marriage } Y \text { Yes(\%) } \\
\text { No }(\%)\end{array}$ & $\begin{array}{c}13(31.7 \%) \\
28(68.3)\end{array}$ & $\begin{array}{c}8(16.7 \%) \\
40(83.3 \%)\end{array}$ & $\begin{array}{l}4(13.8 \%) \\
25(86.2 \%)\end{array}$ & 0.16 \\
\hline
\end{tabular}

1. Values are presented as number (n) of total sample with percentage of infants in each category from the whole sample.

2. Birth weight, family number, family income, and mother's age presented as mean $\pm \mathrm{SD}$.

Table 2: Dietary characteristics of infants according to infant's age ${ }^{1}$

\begin{tabular}{|l|c|c|c|c|c|}
\hline \multirow{2}{*}{ Dietary characteristics } & $\mathbf{6 - 7}$ months & $\mathbf{8}-\mathbf{9}$ months & $\mathbf{1 0}-\mathbf{1 2}$ months & Whole sample & $\begin{array}{l}\boldsymbol{P} \text { - } \\
\text { value }\end{array}$ \\
\cline { 2 - 6 } & Mean \pm SD & Mean \pm SD & Mean \pm SD & Mean \pm SD & 0.61 \\
& $791.10 \pm 124.41$ & $737.68 \pm$ & $713.32 \pm$ & $721.80 \pm 205.70$ & \\
& & 210.62 & 221.18 & & 0.95 \\
\hline CHergy intake (kcal/day) & $98.32 \pm 17.51$ & $91.70 \pm 28.51$ & $98.15 \pm 128.39$ & $94.70 \pm 98.90$ & 0.80 \\
\hline Fat intake (g/day) & $34.17 \pm 4.74$ & $32.18 \pm 9.17$ & $31.76 \pm 9.48$ & $32.30 \pm 8.80$ & 0.80 \\
\hline Protein intake (g/day) & $17.60 \pm 9.94$ & $20.37 \pm 9.94$ & $24.09 \pm 11.59$ & $21.70 \pm 11.00$ & 0.13 \\
\hline Vitamin C (mg/day) & $88.78 \pm 37.20$ & $61.65 \pm 31.67$ & $57.78 \pm 34.63$ & $60.6 \pm 33.3$ & 0.07 \\
\hline Calcium (mg/day) & $799.28 \pm 360.65$ & $567.76 \pm$ & $666.54 \pm 372.72$ & $632.80 \pm$ & 0.23 \\
& & 359.11 & & 360.40 & \\
\hline Iron (mg/day) & $7.25 \pm 6.25$ & $4.67 \pm 3.80$ & $4.81 \pm 4.05$ & $5.20 \pm 4.70$ & 0.01 \\
\hline
\end{tabular}

${ }^{1}$ Data is presented as Mean \pm Standard Deviation (Mean \pm SD). 
Table 3: Percentage of infants taking $<\mathbf{8 0} \%$ DRI $^{1}$ and $>120 \%$ DRI $^{1}$ of energy2

\begin{tabular}{|l|l|l|l|c|}
\hline \multirow{2}{*}{ Energy intake (kcal/day) } & $\mathbf{\%}$ of DRI < 80\% & \% of DRI 80\% - 120\% & \% of DRI > 120\% & \multirow{2}{*}{$\boldsymbol{P}$-value } \\
\cline { 2 - 4 } & n (\%) & n (\%) & n (\%) & 0.00 \\
\hline 6 months & $3(2.5 \%)$ & $6(5.0 \%)$ & $0(0.0 \%)$ & $2(1.7 \%)$ \\
\hline 7 months & $1(0.8 \%)$ & $5(4.2 \%)$ & $0(0.0 \%)$ \\
\hline 9 months & $1(0.8 \%)$ & $10(8.4 \%)$ & $2(1.7 \%)$ \\
\hline 10 months & $12(10.1 \%)$ & $10(8.4 \%)$ & $0(0.0 \%)$ \\
\hline 11 months & $15(12.6 \%)$ & $4(3.4 \%)$ & $3(2.5 \%)$ & \\
\hline 12 months & $23(19.3 \%)$ & $10(8.4 \%)$ & $0(0.0 \%)$ & $7(5.9 \%)$ \\
\hline Whole sample & $11(9.2 \%)$ & $1(0.8 \%)$ & & \\
\hline
\end{tabular}

${ }^{1}$ DRI: Dietary Reference Intake.

${ }^{2}$ Data are presented as number of infants and $\%$ of the infants from the whole sample.

Table 4: Iron intake and its \% from iron DRI according to type of feeding and age.

\begin{tabular}{|c|c|c|c|c|c|c|c|c|}
\hline \multirow{4}{*}{$\begin{array}{l}\text { Age } \\
\text { (months) }\end{array}$} & \multicolumn{8}{|c|}{ Type of feeding } \\
\hline & \multicolumn{3}{|c|}{ Iron Intake (mg) } & \multicolumn{5}{|c|}{$\%$ of Iron DRI ${ }^{2}$} \\
\hline & $\begin{array}{c}\text { Breast } \\
\text { fed } \\
\text { infants } \\
(n)=41\end{array}$ & $\begin{array}{c}\text { Formula } \\
\text { fed infants } \\
(n)=49\end{array}$ & $\begin{array}{c}\text { Mixed } \\
\text { fed } \\
\text { infants } \\
(n)=29\end{array}$ & \multirow[t]{2}{*}{$\begin{array}{l}\text { p- } \\
\text { value }\end{array}$} & $\begin{array}{l}\text { Breast fed } \\
\text { infants } \\
(n)=41\end{array}$ & $\begin{array}{c}\text { Formula } \\
\text { fed infants } \\
(n)=49\end{array}$ & $\begin{array}{c}\text { Mixed fed } \\
\text { infants } \\
(n)=\mathbf{2 9}\end{array}$ & \multirow[t]{2}{*}{$\begin{array}{l}\text { p- } \\
\text { value }\end{array}$} \\
\hline & $\begin{array}{l}\text { Iron } \\
\text { (mg) }\end{array}$ & Iron (mg) & $\begin{array}{l}\text { Iron } \\
\text { (mg) }\end{array}$ & & $\begin{array}{c}\text { \% of Iron } \\
\text { DRI }\end{array}$ & $\begin{array}{c}\text { \% of Iron } \\
\text { DRI }\end{array}$ & $\begin{array}{c}\text { \% of Iron } \\
\text { DRI }\end{array}$ & \\
\hline $\begin{array}{l}\text { 6-6.9 } \\
\text { months }\end{array}$ & $\begin{array}{ll}0.98 & \pm \\
0.98 & \\
\end{array}$ & $7.75 \pm 1.06$ & $\begin{array}{l}4.82 \quad \pm \\
2.28\end{array}$ & \multirow[t]{7}{*}{0.31} & $9.00 \pm 8.88$ & $\begin{array}{l}70.30 \\
9.47 \\
\end{array}$ & $\begin{array}{ll}43.82 & \pm \\
20.78 & \\
\end{array}$ & \multirow[t]{7}{*}{0.97} \\
\hline $\begin{array}{l}7-7.9 \\
\text { months }\end{array}$ & $\begin{array}{ll}4.60 & \pm \\
1.41 & \end{array}$ & $\begin{array}{l}18.01 \pm \\
10.76\end{array}$ & $4.30 \pm 0.0$ & & $\begin{array}{ll}41.80 & \pm \\
12.86 & \\
\end{array}$ & $\begin{array}{l}93.87 \\
44.17 \\
\end{array}$ & $39.00 \pm 0.0$ & \\
\hline $\begin{array}{l}8-8.9 \\
\text { months }\end{array}$ & $\begin{array}{ll}1.93 & \pm \\
0.71 & \end{array}$ & $8.36 \pm 1.23$ & $\begin{array}{l}3.70 \\
3.67\end{array}$ & & $17.55 \pm 6.37$ & $\begin{array}{l}75.66 \\
11.37\end{array}$ & $\begin{array}{l}33.56 \\
33.26\end{array}$ & \\
\hline $\begin{array}{l}9-9.9 \\
\text { months }\end{array}$ & $\begin{array}{l}2.77 \quad \pm \\
2.38\end{array}$ & $6.65 \pm 5.23$ & $\begin{array}{l}4.87 \\
2.62 \\
\end{array}$ & & $\begin{array}{l}24.96 \\
21.72 \\
\end{array}$ & $\begin{array}{l}60.36 \\
47.59 \\
\end{array}$ & $\begin{array}{l}44.33 \\
23.88 \\
\end{array}$ & \\
\hline $\begin{array}{l}10-10.9 \\
\text { months }\end{array}$ & $\begin{array}{ll}2.59 & \pm \\
1.72 & \end{array}$ & $6.97 \pm 4.94$ & $\begin{array}{l}4.56 \\
1.40\end{array}$ & & $\begin{array}{l}23.58 \\
15.68\end{array}$ & $\begin{array}{l}62.90 \\
44.21\end{array}$ & $\begin{array}{l}41.30 \\
\pm 12.78\end{array}$ & \\
\hline $\begin{array}{l}11-12 \\
\text { months }\end{array}$ & $\begin{array}{ll}3.07 & \pm \\
3.45 & \end{array}$ & $6.64 \pm 4.60$ & $\begin{array}{l}3.68 \\
2.39\end{array}$ & & $\begin{array}{l}27.58 \\
31.45\end{array}$ & $\begin{array}{l}60.38 \\
41.65\end{array}$ & $\begin{array}{l}33.35 \\
21.89\end{array}$ & \\
\hline Total & $\begin{array}{ll}2.75 & \pm \\
2.66 & \end{array}$ & $7.82 \pm 5.94$ & $\begin{array}{l}4.23 \\
2.36\end{array}$ & & $\begin{array}{l}24.84 \\
24.23\end{array}$ & $\begin{array}{l}65.11 \\
41.12\end{array}$ & $\begin{array}{l}38.38 \\
21.53\end{array}$ & \\
\hline
\end{tabular}

${ }^{1}$ Data is presented as Mean \pm Standard Deviation (Mean \pm SD) and is considered significantly different at $\mathrm{P}<0.05$. ${ }^{2}$. Intake was calculated according to Dietary Reference Intakes DRI (Food and Nutrition Board, Institute of Medicine, National Academies, 2001).

Table 5: Anthropometric characteristics of Infants according to sex of infant

\begin{tabular}{|l|c|c|c|}
\hline \multirow{2}{*}{$\begin{array}{l}\text { Anthropometric } \\
\text { Measurements }\end{array}$} & Males & Females & P-value \\
\cline { 2 - 4 } & Mean \pm SD & Mean \pm SD & 0.54 \\
\hline Weight $(\mathrm{Kg})$ & $9.56 \pm 1.20$ & $8.66 \pm 1.28$ & 0.41 \\
\hline Length $(\mathrm{cm})$ & $71.54 \pm 9.09$ & $70.99 \pm 3.79$ & 0.87 \\
\hline Head circumference $(\mathrm{cm})$ & $44.54 \pm 1.79$ & $43.05 \pm 1.80$ & 0.24 \\
\hline
\end{tabular}

${ }^{1}$ Data are presented as Mean \pm Standard Deviation (Mean \pm SD) and is considered significantly different at $\mathrm{P}<0.05$

2 (BMI): Body mass index. 
Table 6: Hemoglobin, mean cell volume concentrations and serum ferritin levels of infants according to type of feeding.

\begin{tabular}{|l|c|c|c|c|}
\hline \multirow{2}{*}{ Indicator } & \multicolumn{4}{|c|}{ Type of feeding } \\
\cline { 2 - 5 } & $\begin{array}{c}\text { Breast fed infants } \\
(\mathbf{n})=\mathbf{4 1}\end{array}$ & $\begin{array}{c}\text { Formula fed infants } \\
(\mathbf{n})=\mathbf{4 9}\end{array}$ & $\begin{array}{c}\text { Mixed fed infants } \\
(\mathbf{n})=\mathbf{2 9}\end{array}$ & P-value \\
\hline Hb (gm/l) $\mathbf{1}$ & $105.43 \pm 12.04$ & $115.12 \pm 9.19$ & $112.89 \pm 9.15$ & 0.00 \\
\hline MCV (fl) & $69.95 \pm 7.21$ & $71.39 \pm 4.40$ & $71.31 \pm 5.21$ & 0.44 \\
\hline Ferritin (ug/l) & $28.51 \pm 71.43$ & $39.16 \pm 41.23$ & $39.68 \pm 30.03$ & 0.55 \\
\hline
\end{tabular}

Data is presented as mean $\pm \mathrm{SD}$ and is considered significantly significant at $\mathrm{P}<0.05^{1}$

Table 7: Incidence of anemia, iron deficiency anemia, and depleted iron stores according to type of feeding.

\begin{tabular}{|l|c|c|c|}
\hline \multirow{2}{*}{ Type of feeding } & Anemia & Iron deficiency anemia (IDA) & Depleted iron stores \\
\cline { 2 - 4 } & $\mathrm{n} \%$ & $\mathrm{n} \%$ & $\mathrm{n} \%$ \\
\hline Breastfed & $22(18.5 \%)$ & $9(7.6 \%)$ & $22(18.5 \%)$ \\
\hline Formula-fed & $13(10.9 \%)$ & $3(2.5 \%)$ & $7(5.8 \%)$ \\
\hline Mixed-fed & $9(7.6 \%)$ & $0(0 \%)$ & $4(3.4 \%)$ \\
\hline Total & $44(36.9 \%)$ & $12(10.1 \%)$ & $33(27.7 \%)$ \\
\hline
\end{tabular}

Data are presented as number of infants in type of feeding groups with its percentage (\%) from the total sample.

Table 8: Incidence of iron deficiency anemia, anemia and depleted iron stores of the infants included in the study ${ }^{1}$.

\begin{tabular}{|l|l|l|l|l|l|l|l|}
\hline Iron status & \multirow{2}{*}{$\begin{array}{l}\text { Number of } \\
\text { infants }\end{array}$} & & \multicolumn{2}{l|}{ Hb } & \multicolumn{2}{l|}{ MCV } & \multicolumn{2}{l|}{ Ferritin } \\
\cline { 3 - 8 } & & Sean \pm & Range & Mean \pm SD & Range & $\begin{array}{l}\text { Mean } \\
\text { SD }\end{array}$ & Range \\
\hline Anemia $^{2}$ & 44 & $\begin{array}{l}100.34 \pm \\
8.91\end{array}$ & $\begin{array}{l}68.00 \\
109.00\end{array}$ & & & & \\
\hline $\begin{array}{l}\text { Iron deficiency } \\
\text { anemia (IDA) }\end{array}$ & 12 & $95.91 \pm$ & $80.00-$ & $64.66 \pm 2.42$ & $60.00-$ & $6.66 \pm 2.01$ & $4.00-$ \\
\hline $\begin{array}{l}\text { depleted iron } \\
\text { stores }\end{array}$ & 33 & 8.74 & 107.00 & & 69.00 & & 10.00 \\
\hline
\end{tabular}

${ }^{1}$ Data is presented as Mean \pm Standard Deviation (Mean \pm SD) and its range.

${ }^{2}$ Anemia is defined by hemoglobin $<110 \mathrm{~g} / \mathrm{l}$; iron deficiency anemia by hemoglobin $<110 \mathrm{~g} / \mathrm{l}, \mathrm{MCV}<70 \mathrm{fl}$, and serum ferritin $<12 \mu \mathrm{g} / \mathrm{l}$; and depletion of iron stores by serum ferritin $<12 \mu \mathrm{g} / \mathrm{l}$. 